\title{
Genetic Analysis for Fruit Yield and Its Component Characters in Brinjal (Solanum melongena L.)
}

\author{
Raju Shyadambi", M.H. Sapovadiya, S.B. Chaudhari, \\ N. C. Ghadage and D. Dinesh Varma
}

Department of Genetics and Plant Breeding, Junagadh Agricultural University, Junagadh, Gujarat (India) - 362001

*Corresponding author

\begin{tabular}{|l|}
\hline Ke y w o r d s \\
Brinjal (Solanum \\
melongena L.), \\
Epistasis, \\
Generation mean \\
analysis and Gene \\
action
\end{tabular}

A B S T R A C T

The present investigation was undertaken with a view to generate genetic information on gene effects for 14 quantitative traits in brinjal through generation mean analysis. The experimental material consists of six generations, namely $\mathrm{P}_{1}, \mathrm{P}_{2}, \mathrm{~F}_{1}, \mathrm{~F}_{2}, \mathrm{~B}_{1}$ and $\mathrm{B}_{2}$ of four crosses in brinjal viz., AB-15-07 x GJLB-4 (cross 1), JBR-14-07 x Pant Rituraj (cross 2), NSR-01 x Swarnmani Black (cross 3) and NBR-14-05 x GJB-03 (cross 4). The results indicated that the magnitude and type of gene effects differed for the same trait in different cross combinations. Therefore, for the improvement of particular trait, segregating generations of individual crosses should be handled according to the gene action involved in its inheritance. Additive [d], dominance [h], additive $\mathrm{x}$ additive, dominance $\mathrm{x}$ dominance gene actions were equally important for days to opening of first flower, fruit length (cross 1 and cross 2), fruit girth, number of fruits per plant (except cross 4), plant height, days to last picking (except cross 1), average fruit weight (except cross 4), fruit yield (except cross 4), number of picking (except cross 3), total phenol, total soluble solids (except cross 2) and fruit borer infestation. Classification of gene action showed importance of duplicate type of gene action for most of the characters in most of the crosses. Breeding procedure involving multiple crosses, biparental crosses may be restored to get transgressive segregants. This is especially important to develop inbred lines having superiority in different characters. Such lines can give better hybrids. While in case of complementary type of epistasis, material can be utilized directly in breeding programme.

\section{Introduction}

Vegetables are certain parts of plants that are consumed by humans as food as part of a savory meal. It can be eaten either raw or cooked and play an important role in human nutrition, being mostly low in fat and carbohydrates, but high in vitamins, minerals and dietary fiber. India is the second largest producer of vegetables in the world, next to China. Brinjal is one of the most important tender fruit vegetable crops of our country grown during rainy (kharif), winter (rabi) and spring (summer) seasons.

Brinjal or eggplant (Solanum melongena L.) originated in India which is also considered as center of diversity (Genebus, 1963). It is an 
important solanaceous vegetable crop widely grown in the tropical and sub- tropical regions of the world. Brinjal shares 8.1 per cent in total vegetable production of India, it is grown in an area of 7.29 lakh ha with production of 12.61 million tons and productivity of $18868 \mathrm{~kg} / \mathrm{ha}$ (Anon., 2017).

The crop has a somatic chromosome number of $2 n=2 x=24$ and comprises of three botanical varieties viz., var. esculentum, with round or egg shaped fruits, var. serpentinum with long slender fruits and var. depressum having dwarf stature. Brinjal is highly productive and usually finds its place as the poor man's vegetable (Som and Maity, 2002). It is popular among people of all social strata and hence it is rightly called as "vegetable of masses" (Patel and Sarnaik, 2003). Its immature fruits are used as vegetable and extensively used in various culinary preparations. Due to its quick growth, short duration and photo insensitive in nature, it enables the geneticists and plant breeders to raise two crops in a year, thereby reducing the period for improvement of yield. India being a center of origin, brinjal has a huge genetic diversity in our country which offers much scope for improvement through heterosis breeding.

The ultimate aim in most brinjal breeding programme is to improve the genetic potential for fruit yield. The knowledge about nature and magnitude of fixable and non-fixable type of gene effects, in the control of components of yield is essential in order to achieve the genetic improvement in this crop. Among different biometrical techniques, six parameter model for generation means analysis is the technique which estimate the additive, dominance and epistatic variance. In view of this, in the present investigation, an attempt has been made to detect and quantify the genetic interaction for yield and its component traits.

\section{Materials and Methods}

The experimental materials comprised of six basic generations viz., $\mathrm{P}_{1}, \mathrm{P}_{2}, \mathrm{~F}_{1}, \mathrm{~F}_{2}, \mathrm{~B}_{1}$, and $\mathrm{B}_{2}$ of four crosses. Eight parents viz., AB-1507, GJLB-4, JBR-14-07, Pant Rituraj, NSR01, Swarnmani Black, NBR-14-05 and GJB03 of brinjal were selected from diverse genetic stocks available at the Vegetable Research Station, Junagadh Agricultural University, Junagadh for crossing purpose. Six basic generations viz., $\mathrm{P}_{1}, \mathrm{P}_{2}, \mathrm{~F}_{1}\left(\mathrm{P}_{1} \times \mathrm{P}_{2}\right)$, $\mathrm{F}_{2} \quad\left(\mathrm{~F}_{1}\right.$ selfed $), \mathrm{B}_{1}\left(\mathrm{~F}_{1} \times \mathrm{P}_{1}\right)$ and $\mathrm{B}_{2}\left(\mathrm{~F}_{1} \times \mathrm{P}_{2}\right)$ derived from the four crosses namely, AB-1507 x GJLB-4(cross 1), JBR-14-07 x Pant Rituraj (cross 2), NSR-01 x Swarnmani Black (cross 3) and NBR-14-05 x GJB-03 (cross 4). Experiment was laid-out in Compact Family Block Design (CFBD) with three replications during late kharif, 2018-19 at Vegetable Research Station, Junagadh Agricultural University, Junagadh. The observation were recorded on five randomly selected plants of $\mathrm{P}_{1}, \mathrm{P}_{2}$ and $\mathrm{F}_{1}$, twenty plants from $\mathrm{F}_{2}$ and ten plants from $B_{1}$ and $B_{2}$ generations in each replication for fourteen characters viz., days to opening of first flower, days to first picking, fruit length $(\mathrm{cm})$, fruit girth $(\mathrm{cm})$, number of fruits per plant, number of primary branches per plant, plant height $(\mathrm{cm})$, days to last picking, average fruit weight $(\mathrm{g})$, fruit yield per plant $(\mathrm{kg})$, number of pickings, total phenol (mg GAE/ g FW), total soluble solids $\left({ }^{0} \mathrm{~B}\right)$ and fruit borer infestation $(\%)$. Each hybrid and parents represented single rows of 6 meter length spaced at $90 \mathrm{~cm}$ between rows and $60 \mathrm{~cm}$ between plants. Recommended agronomic practices and plant protection operations were followed to raise good crop. The individual scaling tests (Mather, 1949) and joint scaling test (Cavelli, 1952) were applied to test the adequacy of additivedominance model. When the model was adequate, six parameter model (Hayman 1958) was used to estimate components of different parameters viz., [m], [d], [h], [i], [j] and [1]. 


\section{Results and Discussion}

Results of individual scaling test A, B, C, D and joint scaling test (Table 1) were nonsignificant, the additive-dominance model was found adequate for description of variation in generation means for days to first picking (cross 1 and cross 4 ), number of fruits per plant (cross 4), number of primary branches per plant (cross 1 and cross 4), days to last picking (cross 1), average fruit weight (cross 4), fruit yield per plant (cross 4) and total soluble solids (cross 2). For remaining crosses either all four or any one individual scaling test (A, B, C and D) were found significant. This was also confirmed by significant chi-square values of joint scaling test, indicating involvement of digenic interaction parameters in the inheritance of the characters. These findings were also in consonance with Shinde et al., (2009) in brinjal.

The estimates of gene effects and various contributing traits are given in table 2. The estimates of mean (m) were highly significant for all the traits studied in all crosses which showed the significant difference among the crosses and traits studied.

\section{Gene action}

Days to opening of first flower: In cross AB15-07 x GJLB-4the gene effects viz., ' $\mathrm{m}$ ', additive [d], dominance $[\mathrm{h}]$, additive $\mathrm{x}$ additive [i] and dominance $\mathrm{x}$ dominance [1] were found significant. The sequence of genetic effects in the decreasing order of their magnitudes was $[1]>[\mathrm{i}]>[\mathrm{h}]>[\mathrm{d}]$ indicating the predominance of non-additive gene action over additive gene action. While in case ofJBR-14-07 x Pant Rituraj all the six parameter found significant to explain the variations in this cross. In NSR-01 $x$ Swarnmani Black there was significant digenic parameters like [1]>[i] $>[\mathrm{h}]$ were adequate to explain the variations, meanwhile in crossNBR-14-05 x GJB-03the gene effects viz., ' $\mathrm{m}$ ', additive [d] and dominance $\mathrm{x}$ dominance [1] were found significant. The magnitude of their genetic effects was found more in [1] as compared to [d].The sign of [h] and [1] were found opposite in all the four crosses indicated the predominance of duplicate type of gene interaction. Similar results were found by Rai et al., (2005) and Dhameliya et al., (2009).

Days to first picking: As the scaling test results were non-significant, three parameter model analysis revealed that, significant dominance $[\mathrm{h}]$ gene action was noticed in cross 4 and non-significant in cross 1 . The magnitude of dominance $[\mathrm{h}]$ was higher than additive [d] indicating more importance of dominance gene effects in the inheritance of this trait. Additive and dominance gene action for trait was also reported by Singh et al., (2002). However, in remaining crosses i.e., JBR-14-07 x Pant Rituraj and NSR-01 x Swarnmani Black showed the presence of significant scaling test for days to first picking was confirmed by joint scaling test indicated the existence of non-allelic gene interactions. The gene effects viz., ' $\mathrm{m}$ ', dominance $[\mathrm{h}]$ and additive $\mathrm{x}$ additive [i] were found significant and magnitude of genetic effect found more in [h] as compared to [i] indicating the predominance of non-additive gene action with complementary type of gene action in cross 2 meanwhile the gene effects $v i z$. , ' $m$ ' and additive $\mathrm{x}$ dominance [j] were found significant in cross 3 with duplicate type of gene action to explain the variations for the said trait. These findings were in agreement with Rai et al., (2005) and Dhameliya et al., (2009).

Fruit length $(\mathrm{cm})$ : The components of gene action observed significant in cross 2 in desirable direction for all the components viz., $[\mathrm{m}], \quad[\mathrm{d}],[\mathrm{h}],[\mathrm{i}]$, [j] and [1] indicating importance of additive, dominance and epistatic interactions for expression of this 
character, meanwhile in cross 1 except [j] all the remaining digenic parameters found significant indicating the predominance of non-additive gene action in both cross 1 and 2.In cross 3 the gene effects viz., 'm', additive [d] and additive $\mathrm{x}$ additive [i] were found significant with higher magnitude of [i] as compared to [d], similarlythe gene effects viz., ' $\mathrm{m}$ ', additive [d] and additive $\mathrm{x}$ dominance [j] were found significant. The magnitude of genetic effect found more in [d] as compared to [j] indicating the predominance of additive gene action in both cross 3 and 4 . The sign of [h] and [1] were found opposite in all the four crosses indicated the predominance of duplicate type of gene interaction to explain the variations for this trait. These findings were in agreement with the results of Prasad et al., (2010).

Fruit girth (cm): In cross AB-15-07 x GJLB4the gene effects viz., ' $\mathrm{m}$ ', dominance [h] and additive $\mathrm{x}$ additive [i] were found significant with higher magnitude of [i] indicating the importance of additive along with complementary type of gene action to explain the variations in this cross. In cross 3 the gene effects viz., ' $\mathrm{m}$ ', dominance [h], additive $\mathrm{x}$ additive [i] and additive $\mathrm{x}$ dominance [j] were found significant with sequence of genetic effects in the decreasing order of their magnitudes i.e., $[\mathrm{h}]>[\mathrm{i}]>[\mathrm{j}] \quad$ with complementary gene interaction. In case of cross 2 except [j] all the remaining digenic components found significant and depicted the importance of non-additive gene action, similarly in cross 4 all the gene effects were found significant with the predominance of non-additive type of gene interaction in this cross. The sign of [h] and [1] were found opposite in cross 2 and 4 indicated the predominance of duplicate type of gene interaction to explain the variations for this trait. These results were in agreement with the results of Singh et al., (2002) and Prasad et al., (2010).
Number of fruits per plant: The scaling test results were non-significant, three parameter model analysis revealed that, significant additive [d] gene action was noticed in cross 4indicating more importance of additive gene effects in the inheritance of this trait. Additive and dominance gene action for trait was also reported by Singh et al., (2002). The components of gene action observed significant in cross 2 and 3 in desirable direction for the components viz., [m], [d], [h], [i] and [1] indicating importance of additive, dominance and epistatic interactions for expression of this character mean-while in cross 1the gene effects viz., 'm', additive [d] and additive $x$ dominance [j] were found significant with higher magnitude of [j] as compared to $[\mathrm{d}]$ indicating the predominance of non-additive gene effect. The sign of [h] and [1] were found opposite in cross 1, 2 and 3 indicated the predominance of duplicate type of gene interaction to explain the variations for this trait. These findings were in agreement with Rai et al., (2005) and Dhameliya et al., (2009).

Number of primary branches per plant: As the scaling test results were non-significant, three parameter model analysis revealed that, significant $[\mathrm{h}]$ and $[\mathrm{d}]$ gene action was noticed in cross 1 and 4 and non-significant [d] in cross 4 . The magnitude of dominance [h] was higher than additive [d] indicating more importance of dominance gene effects in the inheritance of this trait. Additive and dominance gene action for trait was also reported by Singh et al., (2002). However, in remaining crosses i.e., JBR-14-07 x Pant Rituraj and NSR-01 x Swarnmani Black showed the presence of significant scaling test for the trait was confirmed by joint scaling test indicated the existence of non-allelic gene interactions, the gene effect ' $m$ ', additive [d] and additive $\mathrm{x}$ dominance [j] were found significant, with higher magnitude of [j] as compared to [d] indicating the importance of 
non-additive gene effect along with complementary gene interaction to explain the variations in number of primary branches per plant. The similar results were reported by Gauravkumar et al., (2004) and Ahmed et al., (2006).

Plant height $(\mathrm{cm})$ : The $\chi^{2}$ value of joint scaling test was significant which supported the findings of simple scaling tests. In cross 1 all the gene effects were found significant with non-additive gene effect along with the predominance of duplicate type of interaction in this cross. In cross 2 the gene effects viz., ' $\mathrm{m}$ ', dominance [h], additive $\mathrm{x}$ additive [i] and dominance $\mathrm{x}$ dominance [1] were found significant. The sequence of genetic effects in the decreasing order of their magnitude was $[1]>[\mathrm{h}]>[\mathrm{i}]$, similarly in cross 3 the gene effects viz., ' $\mathrm{m}$ ', dominance $[\mathrm{h}]$, additive $\mathrm{x}$ additive [i], additive $\mathrm{x}$ dominance [j] and dominance $\mathrm{x}$ dominance [1] were found significant. The sequence of genetic effects in the decreasing order of their magnitudes was $[1]>[\mathrm{h}]>[\mathrm{i}]>[\mathrm{j}]$ indicating the importance of non-additive gene effect with duplicate type of interaction for the trait. In case of cross 4 the gene effect viz., ' $\mathrm{m}$ ', additive [d] and additive $x$ dominance [j] were found significant. The magnitude of gene effect found more in [j] as compared to [d] which depict the importance of complementary type of interaction. These results were in agreement with the results of Singh et al., (2002), Gauravkumar et al., (2004) and Prasad et al., (2010).

Days to last picking: In cross 1, none of the individual scaling tests was found significant. This result also supported by non-significant $\chi^{2}$ value derived from joint scaling test. Thus, the additive-dominance model was fitted very well. All the gene effects viz., 'm', additive [d] and dominance [h] gene effects were observed significant. In cross 2 the gene effect viz., ' $\mathrm{m}$ ' and additive $\mathrm{x}$ dominance [j] were found significant, indicating the importance of non-additive gene action. In case of cross 3the gene effects viz., ' $\mathrm{m}$ ', additive $[\mathrm{d}]$, dominance $[\mathrm{h}]$, additive $\mathrm{x}$ additive [i] and dominance $\mathrm{x}$ dominance [1] were found significant with non-additive gene action. On the other hand cross 4 depicted the predominance of additive gene action with the significant gene effects viz., 'm', additive [d], dominance [h], additive $\mathrm{x}$ additive [i] and additive $x$ dominance $[j]$ were found significant in this cross. The sign of [h] and [1] were found opposite in cross 2, 3 and 4 indicated the predominance of duplicate type of gene interaction to explain the variations for this trait. These findings were in agreement with Rai et al., (2005) and Dhameliya et al., (2009).

Average fruit weight $(g)$ : As the scaling test results were non-significant, three parameter model analysis revealed that, significant [h] and [d] gene action was noticed in cross 4 with more effect of additive gene action. Additive gene action for trait was also reported by Singh et al., (2002). In cross 1the gene effects viz., ' $\mathrm{m}$ ', additive [d] and additive $\mathrm{x}$ dominance [j] were found significant with higher additive effect along with complementary gene action in this cross. In cross 2the gene effects viz., ' $\mathrm{m}$ ', dominance [h], additive $\mathrm{x}$ additive [i] and dominance $\mathrm{x}$ dominance [1] were found significant. The sequence of genetic effects in the decreasing order of their magnitudes was [1] $>[\mathrm{i}]>[\mathrm{h}]$, similarly in cross 3 the gene effects viz., ' $\mathrm{m}$ ', additive $[\mathrm{d}]$, dominance [h], additive $\mathrm{x}$ additive [i] and dominance $\mathrm{x}$ dominance [1] were found significant. The sequence of genetic effects in the decreasing order of their magnitudes was $[1]>[\mathrm{h}]>[\mathrm{i}]>[\mathrm{d}]$ indicating the predominance of duplicate type of interaction in cross 2 and 3 to explain the variations for the said trait. The results were in agreement with Shinde et al., (2009) and Prasad et al., (2010). 
Table.1 Scaling and joint scaling tests for yield and yield attributing traits in brinjal

\begin{tabular}{|c|c|c|c|c|c|c|c|c|c|c|c|c|c|c|}
\hline \multirow[t]{2}{*}{ Scale } & Cross 1 & Cross 2 & Cross 3 & Cross 4 & Scale & Cross 1 & Cross 2 & Cross 3 & Cross 4 & Scale & Cross 1 & Cross 2 & Cross 3 & Cross 4 \\
\hline & \multicolumn{4}{|c|}{ Days to opening of first flower } & \multicolumn{5}{|c|}{ Days to first picking } & & \multicolumn{4}{|c|}{ Fruit length $(\mathrm{cm})$} \\
\hline $\mathbf{A}$ & -0.60 & $5.07 * *$ & $-1.13 *$ & $3.07 * *$ & A & -0.27 & $3.93 *$ & $-4.20 *$ & 1.73 & A & $2.01 * *$ & $-2.55 * *$ & -0.31 & 0.40 \\
\hline B & 0.53 & -1.00 & -1.07 & $3.33 * *$ & B & 1.40 & $5.67 * *$ & 1.00 & 2.20 & B & $3.53 * *$ & -0.75 & -0.57 & $1.62 * *$ \\
\hline $\mathbf{C}$ & $7.40 * *$ & $27.00 * *$ & $9.93 * *$ & $5.47 * *$ & $\mathrm{C}$ & 1.27 & $15.67 * *$ & -0.87 & 1.33 & $\mathrm{C}$ & 0.35 & -0.61 & $-2.55 * *$ & $2.58 * *$ \\
\hline D & $3.73 * *$ & $11.47 * *$ & $6.07^{* *}$ & -0.47 & $\mathrm{D}$ & -0.93 & $3.03 *$ & 1.17 & 0.70 & $\mathrm{D}$ & $-2.60 * *$ & $1.34 * *$ & $-0.84 *$ & 0.28 \\
\hline \multirow[t]{2}{*}{$\begin{array}{l}\text { Joint } \\
\text { scale }\end{array}$} & $42.35 * *$ & $553.61 * *$ & $176.09^{* * *}$ & $47.22 * *$ & $\begin{array}{l}\text { Joint } \\
\text { scale }\end{array}$ & 5.67 & $49.24 * *$ & $8.31 *$ & 5.80 & $\begin{array}{l}\text { Joint } \\
\text { scale }\end{array}$ & $45.46 * *$ & $40.16 * *$ & $13.93 * *$ & $20.50 * *$ \\
\hline & \multicolumn{4}{|c|}{ Fruit girth $(\mathrm{cm})$} & & \multicolumn{4}{|c|}{ Number of fruits per plant } & & \multicolumn{4}{|c|}{ Number of primary branches per plant } \\
\hline $\mathbf{A}$ & $-7.28 * *$ & $-2.45^{*}$ & $-7.62 * *$ & $3.47^{* *}$ & A & $13.53 * *$ & -3.60 & $-6.80 * *$ & -2.33 & A & -0.13 & 0.27 & -0.60 & 0.80 \\
\hline B & $-7.31 * *$ & -0.65 & -1.78 & $6.78^{* *}$ & B & 1.53 & $-8.87 * *$ & -4.60 & -0.47 & B & -0.67 & $-1.60^{* *}$ & 1.40 & 0.40 \\
\hline $\mathbf{C}$ & $-24.41 * *$ & 2.87 & $-14.46 * *$ & 2.87 & $\mathrm{C}$ & 24.47 & $13.73^{*}$ & $7.80 *$ & -3.67 & $\mathrm{C}$ & -0.67 & -1.13 & $1.00^{* *}$ & -0.60 \\
\hline D & $-4.91 * *$ & $2.98 * *$ & $-2.53 *$ & $-3.69 * *$ & D & 4.70 & $13.10^{\text {** }}$ & $9.60 * *$ & -0.43 & $\mathrm{D}$ & 0.07 & 0.10 & 0.10 & -0.60 \\
\hline \multirow[t]{2}{*}{$\begin{array}{l}\text { Joint } \\
\text { scale }\end{array}$} & $200.40 * *$ & $18.70^{* *}$ & $81.80^{* *}$ & $44.43 * *$ & $\begin{array}{l}\text { Joint } \\
\text { scale }\end{array}$ & $18.19 * *$ & $37.51^{* *}$ & $32.69^{* *}$ & 0.70 & $\begin{array}{l}\text { Joint } \\
\text { scale }\end{array}$ & 2.07 & $9.43 * *$ & $9.85^{* *}$ & 4.34 \\
\hline & \multicolumn{4}{|c|}{ Plant height $(\mathrm{cm})$} & & \multicolumn{4}{|c|}{ Days to last picking } & & \multicolumn{4}{|c|}{ Average fruit weight (g) } \\
\hline $\mathbf{A}$ & $21.80 * *$ & 3.67 & 0.60 & 7.00 & A & 1.33 & -1.60 & 1.40 & $-3.00 * *$ & A & $-12.35^{*}$ & 4.79 & $41.16^{* *}$ & 7.79 \\
\hline B & -1.40 & $14.00^{*}$ & $15.00^{* * *}$ & $28.00^{-}$ & B & -0.13 & $11.80^{* * *}$ & $4.00 * *$ & $2.40^{* *}$ & B & 5.58 & 6.64 & $19.79 * *$ & 2.19 \\
\hline $\mathbf{C}$ & -8.47 & -11.53 & -2.00 & $-\overline{-}$ & $\mathrm{C}$ & 5.33 & $13.60^{* *}$ & 0.00 & $-5.40^{*}$ & $\mathrm{C}$ & $-23.88 *$ & $-90.86 * *$ & -6.34 & -0.01 \\
\hline D & $-14.43 * *$ & $-14.60 * *$ & $-8.80^{*}$ & -0.97 & $\mathrm{D}$ & 0.57 & 1.70 & $-2.70 * *$ & $-2.40 *$ & $\mathrm{D}$ & -8.56 & $-51.15 * *$ & $-33.64 * *$ & -4.99 \\
\hline \multirow[t]{2}{*}{$\begin{array}{l}\text { Joint } \\
\text { scale }\end{array}$} & $26.79 * *$ & $13.31 * *$ & $13.83^{* *}$ & $69.92 * *$ & $\begin{array}{l}\text { Joint } \\
\text { scale }\end{array}$ & 7.59 & $258.4 * *$ & $15.44 * *$ & $42.87 * *$ & $\begin{array}{l}\text { Joint } \\
\text { scale }\end{array}$ & $14.16^{* *}$ & $78.89 * *$ & $27.85^{* *}$ & 2.83 \\
\hline & \multicolumn{4}{|c|}{ Fruit yield per plant $(\mathrm{kg})$} & & \multicolumn{4}{|c|}{ Number of pickings } & & \multicolumn{4}{|c|}{ Total phenol (mg GAE/ G FW) } \\
\hline $\mathbf{A}$ & $0.90^{* *}$ & -0.47 & 0.21 & 0.15 & A & $-1.07 * *$ & $-1.00^{* *}$ & -0.73 & $-1.33^{* *}$ & A & $-9.59 * *$ & $39.38 * *$ & $100.15^{* *}$ & $-40.40 * *$ \\
\hline B & $0.53 *$ & $-0.59 *$ & $-0.41 *$ & -0.08 & B & 0.60 & -0.20 & $-1.20 * *$ & 0.27 & B & $-76.51 * *$ & $126.31 * *$ & $146.12 * *$ & $-42.47 * *$ \\
\hline $\mathbf{C}$ & 0.48 & $-2.40 * *$ & $0.67 *$ & 0.05 & $\mathrm{C}$ & 0.53 & $-1.80 * *$ & $-2.00 * *$ & $-1.53 * *$ & $\mathrm{C}$ & 10.89 & $-43.38^{*}$ & $209.53 * *$ & $41.98 * *$ \\
\hline D & $-0.48 * *$ & $-0.66 * *$ & $0.43 * *$ & -0.01 & $\mathrm{D}$ & $0.50 *$ & -0.30 & -0.03 & -0.23 & $\mathrm{D}$ & $48.49 * *$ & $-104.54 * *$ & $-18.37 * *$ & $62.43 * *$ \\
\hline \multirow[t]{2}{*}{$\begin{array}{l}\text { Joint } \\
\text { scale }\end{array}$} & $31.36^{* *}$ & $38.57^{* *}$ & $27.02^{* *}$ & 1.12 & $\begin{array}{l}\text { Joint } \\
\text { scale }\end{array}$ & $33.28 * *$ & $15.77 * *$ & $13.31^{* *}$ & $20.67^{* *}$ & $\begin{array}{l}\text { Joint } \\
\text { scale }\end{array}$ & $1321.84 * *$ & $8469.24 * *$ & $11199.97 * *$ & $459.32 * *$ \\
\hline & \multicolumn{4}{|c|}{ Total soluble solids $\left({ }^{\circ} \mathrm{B}\right)$} & & \multicolumn{4}{|c|}{ Fruit borer infestation (\%) } & & & & & \\
\hline $\mathbf{A}$ & $-0.45 * *$ & -0.03 & $-1.10^{* *}$ & 0.02 & A & 0.04 & $1.00^{* *}$ & $1.15^{* *}$ & $1.68^{* *}$ & & & & & \\
\hline B & $-0.64 * *$ & 0.37 & -0.13 & $-0.57 * *$ & B & $0.85 * *$ & $0.53^{* *}$ & $0.52 * *$ & $0.80^{* *}$ & & & & & \\
\hline $\mathrm{C}$ & -0.33 & 0.07 & -0.13 & $-0.74 * *$ & $\mathrm{C}$ & $11.89 * *$ & $12.73 * *$ & $14.26^{* *}$ & $10.66 * *$ & & & & & \\
\hline D & $0.38 * *$ & -0.18 & $0.55^{* *}$ & -0.09 & $\mathrm{D}$ & $5.50^{* *}$ & $5.60^{* *}$ & $6.29 * *$ & $4.09 * *$ & & & & & \\
\hline $\begin{array}{l}\text { Joint } \\
\text { scale }\end{array}$ & $16.360^{* *}$ & 5.51 & $43.15^{* *}$ & $16.72 * *$ & $\begin{array}{l}\text { Joint } \\
\text { scale }\end{array}$ & $104.18^{* * *}$ & $171.89^{* * *}$ & $289.50^{* * *}$ & $333.43^{* *}$ & & & & & \\
\hline
\end{tabular}


Table.2 Estimates of gene effects for yield and yield attributing traits in brinjal

\begin{tabular}{|c|c|c|c|c|c|c|c|c|c|c|c|c|c|c|}
\hline & Cross 1 & Cross 2 & Cross 3 & Cross 4 & & Cross 1 & Cross 2 & Cross 3 & Cross 4 & & Cross 1 & Cross 2 & Cross 3 & Cross 4 \\
\hline & \multicolumn{4}{|c|}{ Days to opening of first flower } & & \multicolumn{4}{|c|}{ Days to first picking } & & \multicolumn{4}{|c|}{ Fruit length $(\mathrm{cm})$} \\
\hline $\mathbf{m}$ & $52.21 * *$ & $53.81 * *$ & $53.93 * *$ & $52.11 * *$ & $\mathrm{~m}$ & $72.53 * *$ & $75.20 * *$ & $74.96 * *$ & $75.86 * *$ & $\mathrm{~m}$ & $8.64 * *$ & $8.28 * *$ & $8.18 * *$ & $9.17 * *$ \\
\hline (d) & $1.36^{* *}$ & $1.10^{* *}$ & 0.13 & $-2.30 * *$ & (d) & 0.76 & 0.70 & -0.23 & $-1.56^{* *}$ & (d) & $-0.91 * *$ & $-0.41 *$ & $-0.99 * *$ & $-0.92 * *$ \\
\hline (h) & $-5.40 * *$ & $-24.80 * *$ & $-11.70 * *$ & 0.90 & (h) & 0.12 & $-7.03 * *$ & -0.43 & $-5.15^{* *}$ & (h) & $5.01 * *$ & $-2.48 * *$ & 0.08 & 0.85 \\
\hline (i) & $-7.46^{* *}$ & $-22.93 * *$ & $-12.13 * *$ & 0.93 & (i) & & $-6.06^{*}$ & -2.33 & - & (i) & $5.20 * *$ & $-2.68 * *$ & $1.68^{*}$ & -0.56 \\
\hline (j) & -0.56 & $3.03^{* *}$ & -0.03 & -0.13 & (j) & - & -0.86 & $-2.60^{*}$ & - & (j) & -0.76 & $-0.90 * *$ & 0.13 & $-0.61 *$ \\
\hline (l) & $7.53 * *$ & $18.86^{* *}$ & $14.33^{* *}$ & $-7.33 * *$ & (1) & - & -3.53 & 5.53 & - & (l) & $-10.74 * *$ & $5.97 * *$ & -0.80 & -1.46 \\
\hline \multirow[t]{2}{*}{ Epistasis } & $\mathrm{D}$ & $\mathrm{D}$ & $\mathrm{D}$ & $\mathrm{D}$ & Epistasis & - & $\mathrm{C}$ & $\mathrm{D}$ & - & Epistasis & $\mathrm{D}$ & $\mathrm{D}$ & $\mathrm{D}$ & $\mathrm{D}$ \\
\hline & \multicolumn{4}{|c|}{ Fruit girth $(\mathrm{cm})$} & & \multicolumn{4}{|c|}{ Number of fruits per plant } & & \multicolumn{4}{|c|}{ Number of primary branches per plant } \\
\hline (d) & -0.72 & $-2.65 * *$ & -0.90 & $-2.70^{* *}$ & (d) & $5.50 * *$ & $7.56^{* *}$ & $-3.06^{*}$ & $7.09 * *$ & (d) & $0.35 * *$ & $0.76 * *$ & $-0.86^{* *}$ & 0.22 \\
\hline (h) & $8.49 * *$ & $-5.56^{* *}$ & $6.27 * *$ & $8.33^{* *}$ & (h) & -0.50 & $-19.80 * *$ & $-23.23 * *$ & -1.91 & (h) & $0.70 * *$ & 0.96 & -0.13 & $0.87^{* *}$ \\
\hline (i) & $9.81 * *$ & $-5.96 * *$ & $5.06^{*}$ & $7.38^{* *}$ & (i) & -9.40 & $-26.20 * *$ & $-19.20^{* *}$ & - & (i) & - & -0.20 & -0.20 & - \\
\hline (j) & 0.01 & -0.90 & $-2.92 * *$ & $-1.65^{*}$ & (j) & $6.00 * *$ & 2.63 & -1.10 & - & (j) & - & $0.93 * *$ & $-1.00 * *$ & - \\
\hline (l) & 4.77 & $9.06 * *$ & 4.33 & $-17.64 * *$ & (l) & -5.66 & $38.66 * *$ & $30.60 * *$ & - & (l) & - & 1.53 & -0.60 & - \\
\hline \multirow[t]{2}{*}{ Epistasis } & $\mathrm{C}$ & $\mathrm{D}$ & $\mathrm{C}$ & $\mathrm{D}$ & Epistasis & $\mathrm{C}$ & $\mathrm{D}$ & $\mathrm{D}$ & - & Epistasis & - & $\mathrm{C}$ & $\mathrm{C}$ & - \\
\hline & \multicolumn{4}{|c|}{ Plant height $(\mathrm{cm})$} & & \multicolumn{4}{|c|}{ Days to last picking } & & \multicolumn{4}{|c|}{ Average fruit weight (g) } \\
\hline $\mathbf{m}$ & $61.08^{* *}$ & $55.61^{* *}$ & $58.08^{* *}$ & $55.93^{* *}$ & $\mathrm{~m}$ & $151.60^{* *}$ & $155.55 * *$ & $154.85^{* * *}$ & $154.90 * *$ & $\mathrm{~m}$ & $81.66^{* *}$ & $68.65^{* * *}$ & $91.02 * *$ & $88.80^{* *}$ \\
\hline (d) & $6.40^{*}$ & 2.83 & -3.36 & $15.16^{* *}$ & (d) & $4.69 * *$ & -1.40 & $1.60 * *$ & $-1.50 * *$ & (d) & $-12.72 * *$ & -8.19 & $15.01^{*}$ & $-12.03^{* *}$ \\
\hline (i) & $28.86^{* *}$ & $29.20 * *$ & $17.60 *$ & 1.93 & (i) & - & -3.40 & $5.40 * *$ & $4.80 *$ & (i) & 17.11 & $102.29 * *$ & $67.28 * *$ & - \\
\hline (j) & $11.60 * *$ & -5.16 & $-7.20 * *$ & $17.50 * *$ & (j) & - & $-6.70 * *$ & -1.30 & $-2.70 * *$ & (j) & $-8.96^{* *}$ & -0.92 & 10.68 & - \\
\hline (l) & $-49.26 * *$ & $-46.86^{* * *}$ & $-33.20 * *$ & 19.06 & (l) & - & -6.80 & $-10.80 * *$ & -4.20 & (l) & -10.34 & $-113.73 * *$ & $-128.2^{* * *}$ & - \\
\hline \multirow[t]{2}{*}{ Epistasis } & $\mathrm{D}$ & $\mathrm{D}$ & $\mathrm{D}$ & $\mathrm{C}$ & Epistasis & - & $\mathrm{D}$ & $\mathrm{D}$ & $\mathrm{D}$ & Epistasis & $\mathrm{C}$ & $\mathrm{D}$ & $\mathrm{D}$ & - \\
\hline & \multicolumn{4}{|c|}{ Fruit yield per plant (kg) } & & \multicolumn{4}{|c|}{ Number of pickings } & & \multicolumn{4}{|c|}{ Total phenol (mg GAE/ G FW) } \\
\hline $\mathbf{m}$ & $2.62^{* *}$ & $2.41 * *$ & $2.61 * *$ & $2.45^{* *}$ & $\mathrm{~m}$ & $12.23 * *$ & $12.10 * *$ & $12.10 * *$ & $11.93 * *$ & $\mathrm{~m}$ & $99.04 * *$ & $83.93^{* *}$ & $129.29 * *$ & $114.94 * *$ \\
\hline (d) & 0.06 & $0.29 *$ & $0.22 * *$ & $0.21 * *$ & (d) & $-0.43 * *$ & -0.10 & $0.43^{*}$ & -0.30 & (d) & $36.30 * *$ & $-2.62 * *$ & $-4.25 * *$ & -0.98 \\
\hline (h) & $1.28^{* *}$ & $1.85^{* *}$ & $-1.02 * *$ & $0.21 *$ & (h) & -0.80 & $1.10^{*}$ & 0.06 & 0.90 & (h) & $-43.90 * *$ & $210.51 * *$ & $36.37 * *$ & $-120.37 * *$ \\
\hline (i) & $0.95^{* *}$ & $1.32 * *$ & $-0.87 * *$ & - & (i) & $-1.00 *$ & 0.60 & 0.06 & 0.46 & (i) & $-96.98^{* *}$ & $209.08^{* *}$ & $36.73 * *$ & $-124.85^{* *}$ \\
\hline (j) & 0.18 & 0.06 & $0.31 * *$ & - & (j) & $-0.83 * *$ & $-0.40^{*}$ & 0.23 & $-0.80^{* *}$ & (j) & $33.45^{* *}$ & $-43.46 * *$ & $-22.98 * *$ & 1.03 \\
\hline (l) & $-2.39 * *$ & -0.26 & $1.06^{* *}$ & - & (l) & 1.46 & 0.60 & 1.86 & 0.60 & (1) & $183.07 * *$ & $-374.77 * *$ & $-283.1 * *$ & $207.73^{* *}$ \\
\hline \multirow[t]{2}{*}{ Epistasis } & $\mathrm{D}$ & $\mathrm{D}$ & $\mathrm{D}$ & - & Epistasis & $\mathrm{D}$ & $\mathrm{C}$ & $\mathrm{C}$ & $\mathrm{C}$ & Epistasis & $\mathrm{D}$ & $\mathrm{D}$ & $\mathrm{D}$ & $\mathrm{D}$ \\
\hline & \multicolumn{4}{|c|}{ Total soluble solids $\left({ }^{0} \mathrm{~B}\right)$} & & \multicolumn{4}{|c|}{ Fruit borer infestation (\%) } & & & & & \\
\hline $\mathbf{m}$ & $5.78^{* *}$ & $5.67 * *$ & $5.98 * *$ & $5.79 * *$ & $\mathrm{~m}$ & $13.48 * *$ & $13.98 * *$ & $14.63 * *$ & $13.63^{* *}$ & & & & & \\
\hline (d) & 0.05 & 0.02 & $-0.33^{* * *}$ & $0.20 *$ & (d) & $-0.39 * *$ & $0.14 * *$ & $0.23 * *$ & $0.59^{* *}$ & & & & & \\
\hline (h) & $-0.91^{* *}$ & -0.08 & -0.45 & 0.01 & (h) & $-9.85 * *$ & $-10.06 * *$ & $-11.48 * *$ & $-7.58 * *$ & & & & & \\
\hline (i) & $-0.76^{* *}$ & - & $-1.10^{* *}$ & 0.18 & (i) & $-10.99 * *$ & $-11.19 * *$ & $-12.58 * *$ & $-8.18^{* *}$ & & & & & \\
\hline (j) & 0.09 & - & $-0.48^{* *}$ & $0.29 * *$ & (j) & $-0.40 * *$ & $0.23^{* *}$ & $0.31^{* *}$ & $0.44^{* *}$ & & & & & \\
\hline (l) & $1.84 * *$ & - & $2.33 * *$ & 0.36 & (l) & $10.10^{* *}$ & $9.66^{* * *}$ & $10.90 * *$ & $5.70 * *$ & & & & & \\
\hline
\end{tabular}


Fruit yield per plant $(\mathrm{kg})$ : Among the crosses studied, in cross 4 none of the scales were significant for fruit yield per plant indicating that adequacy of additive dominance model and absence of non-allelic interactions between the genes. Hence, three parameter model analysis revealed that in cross 4 significant $[\mathrm{d}]$ and $[\mathrm{h}]$ gene action was noticed with low positive magnitude for inheritance of this trait. The results in cross 4 were also supported by similar findings of Prasad et al., (2010). In cross 1the gene effects viz., ' $\mathrm{m}$ ', dominance $[\mathrm{h}]$, additive $\mathrm{x}$ additive [i] and dominance $\mathrm{x}$ dominance [1] were found significant, depict the non-additive gene action. In cross 2 the gene effects viz., ' $m$ ', additive [d], dominance [h] and additive $\mathrm{x}$ additive [i] were found significant in this cross. In cross 3 the gene effects viz., ' $\mathrm{m}$ ', dominance $[\mathrm{h}]$, additive $\mathrm{x}$ additive [i], additive $\mathrm{x}$ dominance $[\mathrm{j}]$ and dominance $\mathrm{x}$ dominance [1] were found significant, depict the non-additive gene action. The sequence of genetic effects in the decreasing order of their magnitude was $[\mathrm{h}]>[1]>[\mathrm{i}]>[\mathrm{j}]$, depict the nonadditive gene action. The sign of [h] and [1] were found opposite indicated the predominance of duplicate type of interaction in cross 1, 2 and 3. These results were in agreement with the results of Singh et al., (2002) and Prasad et al., (2010).

Number of pickings: In cross 1 the gene effects viz., ' $\mathrm{m}$ ', additive [d], additive $\mathrm{x}$ additive [i] and additive $\mathrm{x}$ dominance [j] were found significant revealed the importance of additive gene effect along with duplicate type of gene interaction in this cross. Similarly in cross 2 the gene effect ' $\mathrm{m}$ ', dominance [h] and additive $\mathrm{x}$ dominance [j] were found significant. The magnitude of genetic effect found more in $[\mathrm{h}]$ as compared to [j] indicating the importance of non-additive gene action in this cross. In case of cross 3 the results of simple scaling tests revealed significant values of $\mathrm{B}$ and $\mathrm{C}$ indicating presence of digenic gene interaction. The $\chi^{2}$ value of joint scaling test was significant which supported the findings of simple scaling tests. But in Hayman's six-parameter model the gene effects viz., ' $\mathrm{m}$ ' and additive [d] were found significant and remaining found non-significant indicated that there may be presence of linkage. Similarly in cross 4gene effects viz., ' $\mathrm{m}$ ' and additive $\mathrm{x}$ dominance [j] were found significant. The sign of [h] and [1] were found same (+) indicated the predominance of complementary type of interaction in cross 2 , 3 and 4.The similar results were reported by Gauravkumar et al., (2004) and Ahmed et al., (2006).

Total phenol ( $m g$ GAE/ $g F W$ ): The $\chi^{2}$ value of joint scaling test was significant which supported the findings of simple scaling tests. In cross 1,2 and 3 all the gene effects were found significant with greater magnitude of non-additive gene effect along with the predominance of duplicate type of interaction in these crosses. In cross 4the gene effects viz., ' $\mathrm{m}$ ', dominance $[\mathrm{h}]$, additive $\mathrm{x}$ additive [i], and dominance $\mathrm{x}$ dominance [1] were found significant. The sequence of genetic effects in the decreasing order of their magnitude was $[1]>[\mathrm{i}]>[\mathrm{h}]$ depict the predominance of non-additive gene action for the said trait. These results were in agreement with the results of Singh et al., (2002) and Prasad et al., (2010).

Total Soluble Solids $\left({ }^{0} \mathrm{~B}\right)$ : Among all the scaling tests none of the individual scaling test was found significant in cross 2 indicating the absence of epistasis for this trait which was supported by non-significant $\chi^{2}$ value derived from joint scaling test. Thus, the additive-dominance model was fitted very well. On the other hand in cross 1 the gene effects viz., ' $\mathrm{m}$ ', dominance [h], additive $\mathrm{x}$ additive [i] and dominance $\mathrm{x}$ dominance [1] were found significant with the predominance 
of duplicate type of interaction. In cross 3 the gene effects viz., 'm', additive [d], additive $\mathrm{x}$ additive [i], additive $x$ dominance [j] and dominance $\mathrm{x}$ dominance [1] were found significant. The sequence of genetic effects in the decreasing order of their magnitudes was $[1]>[\mathrm{i}]>[\mathrm{j}]>[\mathrm{d}]$ indicated the importance of non-additive gene action along with duplicate type of gene interaction. Similarly in cross 4 the gene effects viz., ' $\mathrm{m}$ ', additive [d] and additive $\mathrm{x}$ dominance [j] were found significant. The magnitude of gene effects found more in [j] as compared to [d] indicating the importance of non-additive gene effect along with complementary interaction to explain variations in this cross. These findings were in agreement with Rai et al., (2005) and Dhameliya et al., (2009).

Fruit borer infestation (\%): The results of simple scaling tests revealed the presence of digenic gene interaction. Further, the $\chi^{2}$ value of joint scaling test was significant which supported the findings of simple scaling tests. According to six-parameter model all the gene effects were found significant. The sequence of genetic effects in the decreasing order of their magnitudes was $[\mathrm{i}]>[\mathrm{l}]>[\mathrm{h}]>[\mathrm{j}]$ $>[\mathrm{d}]$ depicting the presence of additive gene effect along with duplicate type of gene interaction to explain the variations in all the four crosses for fruit borer infestation. These results were in agreement with the results of Singh et al., (2002), Gauravkumar et al., (2004) and Prasad et al., (2010).

Overall, it can be concluded from the present study that fruit yield per plant and its component traits recorded in four brinjal crosses were governed by additive, dominance and digenic epistasis gene effects along with duplicate type of gene action. When additive as well as non-additive effects are involved, a breeding scheme efficient in exploiting both types of gene effects should be employed. Hence, bi-parental mating or few cycles of recurrent selection may give fruitful results for genetic improvement of these traits in brinjal.

\section{References}

Ahmed, N., Mehdi, M., Nayeema, J. and Singh, A. K. 2006.Inheritance of Quantitative Characters in Eggplant (Solanum melongena L.).Indian J. Hort., 63(2): 218-220.

Anonymous. 2017. Area and production of horticulture crops-all India. Department of Agriculture Cooperation and Farmers Welfare. Available at http:agricoop.nic.in accessed on 07 February 2018.

Cavalli, L. L. 1952. An analysis of linkage in quantitative inheritance. In "Quantitative Inheritance". Ed. E. C. R. Reeve and C. H. Waddington, HMSO, London. pp. 135-144.

Dhameliya, H. R. and Dobariya, K. L. 2009. Gene effects for fruit yield and its components in brinjal (Solanum melongena L.).Veg. Sci., 36: 106-108.

Gaurav Kumar, J. P., Srivastav, J. P. and Singh, S. K. 2004.Inheritance of Yield and Component Traits in Brinjal (Solanum melongena L.)Veg. Sci., 31(1): 26-29.

Genebus, V. L. 1963. Egg plants of India as initial materials for breeding. Trud. Pariklad. Bot. Genet. Selekc (Bull. Appl. Bot. Gen. Pl. breeds), 35: 36-45.

Hayman, B. I. 1958. The separation of epistatic from additive and dominance variation in generation. Heredity, 12: 371-390.

Mather, K. 1949. Biometrical genetics. Methuen and Co. Ltd., London.

Patel, K. K. and Sarnaik, D. A. 2003.Performance study of long fruited genotypes of Brinjal under Rajpur conditions. Orissa J. Hort. 31:74-77.

Prasad, V., Dwivedi, V. K., Deshpande, A. A. 
and Singh, B. K. 2010.Gene action of economic traits in brinjal (Solanum melongena L.). Veg. Sci., 37: 97-99.

Rai, N., Yadav, D. S., Patel, K. K. and Yadav, R. K. 2005. Genetics of earliness in brinjal (Solanum melongena L.). Veg. Sci., 32: 44-46.

Shinde, K. G., Warade, S. D., Kadam, J. H., Sanap, P. B. and Bhalekar, M. N. 2009. Generation mean analysis in brinjal (Solanum melongena L.). Veg. Sci., 36: 31-40.
Singh, M., Kalloo, G., Banerjee, M. K. and Singh, S. N. 2002. Genetics of yield and its components characters in brinjal (Solanum melongena L.). Veg. Sci., 29:24-26.

Som, M. G. and Maity, J. K. 2002. Brinjal, In: Bose, T. K., Kabir, J., Maity, T. K., Parthasarthy, V. A. and Som, M. G., vegetable crops $\left(3^{\text {rd }}\right.$ Ed.). Nayapokash Publishers. Kolkatta, 1: 265-344.

\section{How to cite this article:}

Raju Shyadambi, M.H. Sapovadiya, S.B. Chaudhari, N.C. Ghadage and Dinesh Varma, D. 2019. Genetic Analysis for Fruit Yield and Its Component Characters in Brinjal (Solanum melongena L.). Int.J.Curr.Microbiol.App.Sci. 8(06): 2903-2912.

doi: https://doi.org/10.20546/ijcmas.2019.806.349 